\title{
Application of Hybrid Process of Coagulation/ Flocculation and Membrane Filtration to Water Treatment
}

\author{
Rosângela Bergamasco ${ }^{1}$, Angélica Marquetotti Salcedo Vieira ${ }^{1}$, \\ Letícia Nishi ${ }^{1}$, Álvaro Alberto de Araújo ${ }^{2}$ and Gabriel Francisco da Silva ${ }^{2}$ \\ ${ }^{1}$ Universidade Estadual de Maringá, \\ ${ }^{2}$ Universidade Federal de Sergipe, \\ Brazil
}

\section{Introduction}

Nowadays, the concern about contamination of aquatic environments has increased, especially when water is used for human consumption (Madrona et al., 2010). Contamination of water resources, especially in areas with inadequate sanitation and water supply, has become a risk factor for public health, with water playing a role as a vehicle for transmission of biological agents (viruses, bacteria, and parasites) as well as a source of contamination by chemicals (industrial effluents). Among the waterborne diseases, enteric diseases are most frequent. Approximately 19\% of waterborne gastroenteritis outbreaks in the United States are attributed to protozoan parasites (Lindquist, 1999), particularly Giardia and Cryptosporidium species, due to their wide distribution in the environment, high incidence in the population, and resistance to conventional water treatment (Iacovski et al., 2004).

Giardia duodenalis is a flagellated protozoan parasite that causes giardiasis. The cysts are transmitted by fecal-oral route in a direct (person to person) or indirect way (contaminated water and food). In humans it can cause from self-limited to chronic enteritis, debilitating diarrhea with steatorrhea and weight loss (Rey, 2001). Cryptosporidium is a genus of protozoan parasites with several species that have been treated as a public health problem, especially after the advent of HIV/AIDS (Fayer, 2004). In immune depressed individuals it causes more serious infection; in some cases, the patient can die if untreated. It is considered an opportunistic parasite (Rey, 2001).

Despite regulations and control measures turning to be more and more stringent, outbreaks of waterborne Cryptosporidium spp. and Giardia spp. have been reported worldwide (United States Environmental Protection Agency [USEPA], 1996; Centers for Disease Control and Prevention [CDC], 2006). Therefore, the treatment applied to the collected water must ensure that it is free of pathogens and chemicals that pose health risks, when distributed by the water supply system. Furthermore, physicochemical parameters must meet the drinking water standards required by the laws of each country (Bergamasco et al., 2011). Thus, there 
is great importance in either the development of more sophisticated treatments or the improvement of the current ones.

In addition to these microorganisms, many other impurities can harm human health if not reduced or eliminated. They do not approach each other naturally during the coagulation/ flocculation process, being necessary the presence of a coagulant agent. Coagulation and flocculation processes are essential parts of water treatment, and the clarification of water using coagulants is practiced since ancient times (International Water Association [IWA], 2010). Alum has been the most widely used coagulant because of its proven performance, cost effectiveness, relative easy handling, and availability. Recently, much attention has been drawn on the extensive use of alum. According to Driscoll \& Letterman (1995), the utilization of alum has raised a public health concern because of the large amount of sludge produced during the treatment and the high level of aluminum that remains in the treated water. McLachlan (1995) discovered that the intake of a large quantity of alum salt may cause Alzheimer disease.

Among the new techniques for drinking water treatment is the use of natural coagulants, aiming at a better quality of treated water by reducing the use of chemicals and also due to others advantages of natural coagulants. The biopolymers may be of great interest since they are natural low-cost products, characterized by their environmentally friendly behavior. Advantages of natural coagulant/flocculants have led some countries, like Japan, China, India, and United states, to adopt the use of natural polymers in surface water treatment do produce drinking water (Kawamura, 1991). The application of these coagulants in the coagulation/flocculation process has been successfully performed to remove turbidity, color, and natural organic matter (NOM) from natural water in order to produce clean potable water.

Thus, considering the coagulation step, the use of natural polyelectrolytes such as chitosan and Moringa oleifera (moringa) could be an option with many advantages over chemical agents, particularly the biodegradability, low toxicity, low residual sludge production, and less risks to health. Polyelectrolytes such as chitosan have a large number of surface charges that increase the efficiency of the coagulation process. Regarding the moringa, many researchers are currently seeking to identify the compound responsible for the coagulating characteristic of the seed of this plant, although there are still no definitive conclusions. It is known that it is a protein or polypeptide with coagulant properties (Ndabigengesere et al., 1995; Okuda et al., 2001; Ghebremichael et al., 2005). According to Davino (1976) the mechanism of coagulation/flocculation caused by the protein found in the seed of Moringa oleifera Lam resembles the mechanism caused by polyelectrolytes.

The use of coagulants for drinking water treatment, in spite of being efficient in the removal of most contaminants, is not able to generate water of high potability standards, which leads to the necessity of the simultaneous use of other techniques. Membrane filtration technique is already widely recognized and can be implemented in combination with coagulation processes.

This way, this chapter will look at the use of alternative techniques for water treatment based on the use of natural coagulants (chitosan and moringa seeds) associated with the membrane filtration process (micro and ultrafiltration) to obtain drinking water for human consumption. 


\subsection{Chitosan}

Chitosan is a linear copolymer of d-glucosamine and N-acetyl-dglucosamine produced by the deacetylation of chitin, a natural polymer of major importance and the second most abundant natural polymer in the world, after cellulose (Rinaudo, 2006). It is described as a cationic polyelectrolyte and is expected to coagulate negatively charged suspended particles found in natural waters with increased turbidity (Divakaran \& Pillai, 2002). Chitosan has been investigated as coagulant/flocculant for the removal of impurities from natural water and wastewater (Kawamura, 1991; Klopotek et al., 1994) because it can be conditioned and used for pollutant complexation in different forms, from water-soluble forms to solid forms (Renault et al., 2009). Some of the applications proposed for chitosan are: (i) removal of turbidity (Divakaran \& Pillai, 2002; Bergamasco et al., 2011), natural organic matter (NOM) and color (Eikebrokk, 1999); (ii) inactivation of bacteria (Chung et al., 2003); and (iii) metal removal with higher efficiency when associated with ultrafiltration (Verbych et al., 2005).

The use of chitosan as coagulant in the coagulation/flocculation process (CFQ) for surface water treatment was studied by Bergamasco et al. (2011), achieving satisfactory results regarding color and turbidity removal, with values above $87 \%$. The surface water sample in this case was from the Pirapó River at Maringá - PR, Brazil, with initial turbidity of 240 NTU and initial color of $1045 \mathrm{Hu}$. The chemical oxygen demand (COD) was initially of 19,3 $\mathrm{mgO}_{2} / \mathrm{L}$ and it was reduced in $59.9 \%$ after treatment with chitosan, showing that the higher coagulation/flocculation of chitosan is related with the compounds that give color and turbidity to surface water.

The efficiency of the use of chitosan is more evident when compared with the process of coagulation/flocculation using aluminum sulfate as coagulant (CFS). The main difference in removal efficiency occurs when evaluating the removal of COD and TDS (Total dissolved solids). Comparing CFQ and CFS processes, COD removal efficiency was 59.9\% using CFQ and $38.1 \%$ using CFS, and TDS removal was $41.9 \%$ for CFQ and $7.5 \%$ for CFS. In the same study, Bergamasco et al. (2011) observed that coagulation with aluminum sulfate generated sludge with SVI (sludge volume index) of $38.7 \mathrm{mg} / \mathrm{mL}$, and the sludge formed by coagulation using chitosan showed SVI of $56.8 \mathrm{mg} / \mathrm{mL}$. According to McLachlan (1995), the biggest advantage of chitosan over aluminum sulfate as coagulant is the fact that it is biodegradable, generating an easy to handle organic sludge that can be taken to a common landfill. Furthermore, chitosan improves the sedimentation step, as the flocs are more compact.

In a study by Eikebrokk \& Saltnes (2001), it was verified that the fractions of color and organic carbon removal, with chitosan concentration of $4.0 \mathrm{mg} / \mathrm{L}$, were 70 and $30 \%$, respectively. In this work the authors also compared chitosan with metallic coagulants, otaining a reduction of $50 \%$ in the generated sludge when using chitosan, solving this way the problem of the concentration of trace metals in treated water. Still, the sludge disposal was simplified due to its biodegradability characteristics.

One can verify that chitosan presents good removal of turbidity and color, and is advantageous in terms of generated sludge, which can be disposed of in ordinary landfills, since it is biodegradable and has no trace metals. 


\subsection{Moringa oleifera}

Moringa oleifera (moringa) is a tropical plant belonging to the family Moringaceae (Katayon et al., 2006), a single family of shrubs with 14 known species. Moringa is native of India but is now found throughout the tropics (Bhatia et al., 2007). Moringa seeds contain a non-toxic natural organic polymer which is an active agent with excellent activity and coagulating properties. The tree is generally known in the developing world as a vegetable, a medicinal plant, and a source of vegetable oil (Katayon et al., 2006). Its leaves, flowers, fruits, and roots are used locally as food ingredients. The medicinal and therapeutic properties of moringa have led to its utilization as a cure for different ailments and diseases, physiological disorders, and in Eastern allopathic medicine (Akhtar et al., 2007). Additionally, the coagulant is obtained at extremely low or zero net cost (Ghebremichael et al., 2005).

If moringa is proven to be active, safe, and inexpensive, it is possible to use it widely for drinking water and wastewater treatment. Besides, moringa may yet have financial advantages bringing more economic benefits for the developing countries (Okuda et al., 1999).

The moringa seed has a protein that when solubilized in water is able to promote coagulation and flocculation of compounds that cause color and turbidity in highly turbid water. Several studies have also shown their effective antimicrobial and antifungal capacity, thereby contributing to good water quality at low cost (Chuang et al., 2007; Coelho et al., 2009).

The process used to obtain the coagulant (which would be mainly constituted by the protein in the seed) is usually performed with the solubilization of the protein in water under stirring and filtration, but the use of salts is able to promote a greater solubilization of this protein in the medium, which would favor the coagulation/flocculation process.

Madrona et al. (2010) evaluated the extraction of the coagulant protein in the presence of potassium chloride $(\mathrm{KCl})$ at different concentrations. The authors have shown that greatest coagulation efficiencies are achieved with $\mathrm{KCl} 1 \mathrm{~mol} / \mathrm{L}$, reaching nearly 100\% removal of color and turbidity from water with initial turbidity of 850 NTU. In the same study, conducted by Madrona (2010), the author evaluated the effectiveness of other salts in the coagulant extraction process, such as magnesium chloride $\left(\mathrm{MgCl}_{2}\right)$ and sodium chloride $(\mathrm{NaCl})$, compared with $\mathrm{KCl}$, all at a concentration of $1 \mathrm{~mol} / \mathrm{L}$. A protein content of 4499 $\mathrm{mg} / \mathrm{L}$ was achieved for the extraction using $\mathrm{NaCl}$, and $4818 \mathrm{mg} / \mathrm{L}$ using $\mathrm{KCl}$. The process of protein extraction with $\mathrm{MgCl}_{2}$ was able to release only $950 \mathrm{mg} / \mathrm{L}$ of protein in solution, which is very close to the concentration released by the extraction with water $(873 \mathrm{mg} / \mathrm{L})$.

Moringa has been found to be ineffective as a natural coagulant for low turbidity drinking water but effective for high turbidity water in previous studies (Okuda et al., 2001). This was verified in a study by Nishi (2011). The authors obtained values of color and turbidity removal over $90 \%$ when the water to be treated showed high values of initial turbidity, between 350 and 450 NTU. A moringa concentration of $150 \mathrm{mg} / \mathrm{L}$ would have been sufficient to achieve this level of removal. The coagulant derived from moringa seeds, as it contains a certain amount of organic matter, can give color and turbidity to the treated water. Thus, when water with low initial turbidity undergoes coagulation/flocculation, depending on the concentration of moringa coagulant used, the effect of turbidity and color 
removal is not as satisfactory as the level of removal obtained for these parameters using this coagulant in the treatment of high turbidity water. In this case the effect of the coagulant protein overlaps the additional organic load and the removal of the evaluated parameters increases.

An important point to be considered when using moringa as a coagulant is related to the $\mathrm{pH}$ of the water to be treated. For chemical coagulants, water $\mathrm{pH}$ adjustment is necessary for the flakes to be properly formed. In the case of the moringa, there is no need for this adjustment, and this parameter is not changed after treatment, as evidenced by Vieira et al. (2010). Moringa is an efficient coagulant in a wide $\mathrm{pH}$ range (6-8), which is an advantage compared with other coagulants, as the $\mathrm{pH}$ adjustment step can be eliminated in the coagulation/flocculation processes.

\subsection{Coagulation/flocculation and membrane filtration}

In conventional water treatment plants, the coagulation/flocculation process is followed by filtration. However, nowadays, membrane separation has been widely studied for potable water production, since the MF/UF membranes are physical barriers that are able to efficiently remove suspended particles and colloids (Xia et al., 2007; Guo et al., 2009), turbidity, bacteria, algae, parasites, and viruses for clarification and disinfection purposes (Guo et al., 2009), as well as to control trihalomethane precursors (Bottino et al., 2001).

To overcome the problems caused by natural organic matter (NOM) in MF and UF applications, conjunctive use of coagulation and membranes is becoming more attractive for water treatment because the coagulation is an opportunity to join NOM with other particles present in water before NOM reaches the membrane surface. Application of the coagulation and ultrafiltration unit operations contributes to the improvement of treated water quality and the enhancement of the membrane performance. In comparison with conventional processes such as coagulation, flocculation, sedimentation and/or flotation, and rapid or slow sand filtration, MF/UF technology has many advantages such as superior quality of treated water, much greater compactness, easier control of operation and maintenance, use of fewer chemicals, and lower production of sludge (Bergamasco et al., 2009). The combined processes of coagulation/flocculation followed by micro or ultrafiltration usually result in better water quality, since the membrane processes often function as a polishing step in water treatment, being able to remove the impurities which are not removed by coagulation/flocculation processes. In addition, unlike the conventional filtration process, micro/ultrafiltration can retain bacteria and other microorganisms.

Bouchard et al. (2003) studied the processes of microfiltration and coagulation/ microfiltration, using ferric chloride and aluminum sulfate as coagulants in the combined process. Microfiltration tests were performed in a mini-module of submerged cross-fiber Zenon membranes, with porosity of $0.1 \mu \mathrm{m}$. For the combined process, the results obtained were $60 \%$ removal of TOC and a reduction of more than $80 \%$ of the compounds that absorb $\mathrm{UV}$ at $254 \mathrm{~nm}$. The coagulation/microfiltration process was shown to be beneficial, allowing a significant reduction in membrane fouling. These results were already expected, because when coagulation occurs, colloids are destabilized and cluster forming larger flocs, thus contributing to reduce membrane fouling. Comparing the processes of ultrafiltration and coagulation/ultrafiltration, using ferric chloride as a coagulant agent, removal of TOC and 
compounds that absorb UV at $254 \mathrm{~nm}$ of $30 \%$ and $60 \%$, respectively, was observed for the ultrafiltration process. For the combined coagulation/ultrafiltration, the removal of TOC and compounds that absorb UV at $254 \mathrm{~nm}$ increased to 60 and $80 \%$, respectively (Bouchard et al., 2003).

Konradt-Moraes (2004) studied the combined process of coagulation/flocculation/ ultrafiltration using ceramic membrane with pore size of $0.05 \mu \mathrm{m}$ and transmembrane pressure of 2 bar. Under optimum conditions of coagulation and flocculation for the biopolymer chitosan, removal of color, turbidity, compounds that absorb UV at $254 \mathrm{~nm}$, nitrite, phosphate, total coliforms, and Escherichia coli close to $100 \%$ and TOC removal of $75 \%$ were achieved. Thus, according to Konradt-Moraes (2004), there is great potential in the use of the combined coagulation/flocculation/membrane separation process. However, few research papers have been published to date, and therefore a wide range of study possibilities is open, that can lead to a deeper knowledge of the variables involved in the process as a whole, which in turn allows not only process scale-up, but also its transfer to the companies responsible for public drinking water supply.

\section{Experimental results - Case studies}

The case studies presented below used the processes of coagulation/flocculation with natural coagulants and membrane filtration for removing color, turbidity, Giardia and Cryptosporidium, to obtain drinking water for human consumption.

The first case describes the utilization of chitosan as natural coagulant and ceramic ultrafiltration membranes in pilot scale. The second case deals with moringa and polymeric microfiltration membranes in a bench-scale filtration module. Both cases used surface water from the Pirapó River, which serves a population of over 300,000 inhabitants in the city of Maringá, Brazil.

\subsection{Process of coagulation/flocculation with chitosan followed by ultrafiltration for surface water treatment}

A pilot plant, shown in Figure 1, has been used by the research group headed by the researcher Professor Rosângela Bergamasco, in the Environmental Preservation and Control Laboratory at the State University of Maringá, Brazil. This unit has been the basis for studies of water purification processes that are subsequent to coagulation/flocculation using natural coagulants such as chitosan and Moringa oleifera. These studies, based on the treatment of water from the Pirapó River, which is responsible for supplying the city of Maringá - PR, Brazil, have demonstrated the effectiveness of the evaluated coagulants, as well as the applicability of the combined processes, yielding high-quality water within the specifications required by Brazilian law. The surface water characterization is presented in Table 1.

In the study conducted by Bergamasco et al. (2011), the removal of UV-254nm absorbing compounds showed a significant increase when the hybrid process was used, changing from $85.8 \%$ with CFQ to $99.4 \%$ with CFQ-UF at 2 bar. The results achieved in the filtration with ceramic membranes of stainless steel with $\mathrm{Al}_{2} \mathrm{O}_{3} / \mathrm{ZrO}_{2}(0.1 \mu \mathrm{m})$ (TAMI, France), at transmembrane pressures of 1 and 2 bar are presented in Table 2. The UV absorbance of 
organic matter, in the range of $254-280 \mathrm{~nm}$, reflects the presence of unsaturated double bonds and п-п electron interactions such as in aromatic compounds. However, it is known that natural organic matter (NOM) is a mixture of organic compounds called humic materials, but proteins, polysaccharides and other classes of biopolymers also contribute to NOM. This indicates that besides the compounds detected by UV-254nm absorption, other organic compounds may also be present in surface water, and therefore this parameter is not a suitable indicator of NOM removal. Other parameters should be considered for a better understanding of the process.

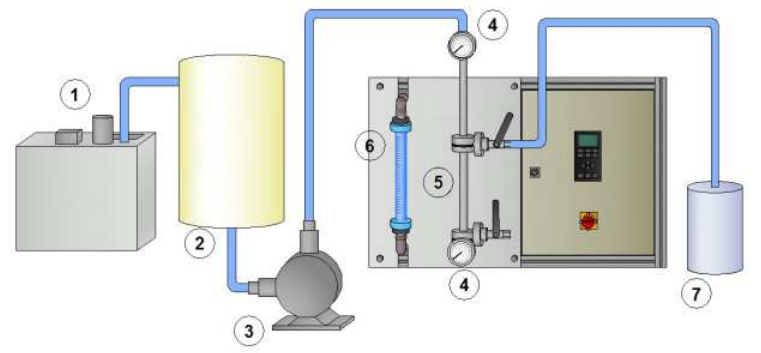

Fig. 1. Schematic diagram of the micro/ultrafiltration experimental unit. 1- thermostatic bath; 2-feed tank; 3- pump; 4- manometers; 5- membrane filtration module; 6-flowmeter (rotameter); 7 - permeate.

\begin{tabular}{c|c}
\hline Water quality parameter & Values \\
\hline Apparent color $(\mathrm{Hu})^{(1)}$ & 1695 \\
True color $(\mathrm{Hu})^{(1)}$ & 1045 \\
Turbidity $(\mathrm{NTU})^{(2)}$ & 240 \\
Chemical oxigen demand (COD) $\left(\mathrm{mgO}_{2} / \mathrm{L}\right)$ & 19.3 \\
Total organic carbon (TOC) $(\mathrm{mgC} / \mathrm{L})$ & 6.4 \\
pH & 0.923 \\
UV-254nm absorbing compounds (UV-254nm) $\left(\mathrm{cm}^{-1}\right)$ & 8.17 \\
Total suspended solids (TSS) $(\mathrm{mg} / \mathrm{L})$ & 1332 \\
Total dissolved solids (TDS) $(\mathrm{mg} / \mathrm{L})$ & 228 \\
Total coliforms $(\mathrm{CFU} / 100 \mathrm{~mL})^{(3)}$ & 3955 \\
Escherichia coli (CFU/100 $\mathrm{mL})^{(3)}$ & 800 \\
\hline
\end{tabular}

1. $\mathrm{Hu}=\mathrm{mg}_{\mathrm{Pt}-\mathrm{Co}} / \mathrm{L}$

2. $\quad \mathrm{NTU}=$ Nefelometric turbidity unit

3. $\mathrm{CFU} / 100 \mathrm{~mL}=$ Colony forming units per $100 \mathrm{~mL}$ of water sample

Table 1. Characterization of the surface water from Pirapó River

Filtration tests were performed to characterize the flow of pure water through the membranes, using deionized water. Flux was calculated using Equation 1, where $\mathrm{f}_{\text {permeate }}$ is the permeate flux, $\mathrm{m}$ is the mass of collected water, $\rho 25^{\circ} \mathrm{C}$ is water density at $25^{\circ} \mathrm{C}, \Delta \mathrm{t}$ is the time interval during which water was collected, and Am is the filtering area of the membrane. 


$$
\mathrm{f}_{\text {permeate }}=\frac{\mathrm{m}}{\rho 25^{\circ} \mathrm{C} \times \Delta \mathrm{t} \times \mathrm{Am}}
$$

The removal efficiency for each parameter analyzed in the different treatment processes was calculated from Equation 2, where $\mathrm{Ci}$ and $\mathrm{Cf}$ are the initial and final concentrations, respectively, for each parameter.

$$
\% \text { Removal efficiency }=\left(\frac{C i-C f}{C i}\right) \times 100
$$

Deionized water (DW) fluxes were determined before each experiment (Ji) and after the filtration of solutions SW, CFQ and CFS (Jf) to determine the fouling of the membrane. The percentage of fouling $(\% \mathrm{~F})$ was calculated according to Equation 3, proposed by Balakrishnan et al. (2001), using the steady-state flux values, which assume that the flux tends to constant values. The percentage of fouling represents a decrease in the deionized water flux after tests with contaminated water.

$$
\% F=\frac{(J i-J f)}{J i} \times 100
$$

In Equation 3, \% F is the percentage of membrane fouling, Ji is the initial water flux obtained in the first filtration with deionized water and Jf is the final water flux obtained by filtration of deionized water after the filtration of surface water.

The parameters apparent color, turbidity, and $\mathrm{pH}$ were evaluated according to the Standard Methods (American Public Health Association [APHA], 1995). Turbidity measurements were conducted using a turbidimeter $(\mathrm{HACH}, 2100 \mathrm{P})$. A digital $\mathrm{pH}$ meter (Digimed DM-2) was used for $\mathrm{pH}$ measurements. Color measurements were conducted using $\mathrm{HACH}$ DR/2010 spectrophotometer - Method 8025. COD values were determined using HACH DR/2010 - Method 10129. TOC was determined using an Aurora 1030C TOC Analyzer with 1088 Rotary TOC Autosampler. Absorbance measurements at $254 \mathrm{~nm}$ were performed using a Logen Scientific UV-Vis spectrophotometer. UV absorbance at $254 \mathrm{~nm}$ was also used in this study as an indication of the removal of organics from water. UV absorbance is commonly used as an index of the aromatic level (Kim \& Yu, 2005).

Comparing CFQ and CFS processes, the main differences in removal efficiency are observed with respect to COD removal (59.9\% using CFQ and 38.1\% using CFS) and TDS removal ( $41.9 \%$ for CFQ and $7.5 \%$ for CFS). It is also observed in Table 2 that the process of coagulation/flocculation with the natural coagulant chitosan was very effective in removing compounds responsible for color and turbidity, as well as UV-254nm absorbing compounds. Similar results were observed by other authors such as Roussy et al. (2005) and Rizzo et al. (2008).

The working conditions for the experiments presented in Table 2 were as follows: The $\mathrm{pH}$ was adjusted to 5.0 and concentration of natural chitosan coagulant was $1.0 \mathrm{mg} / \mathrm{L}$. When using aluminum sulfate as coagulant $(15 \mathrm{mg} / \mathrm{L}), \mathrm{pH}$ was maintained at 7.0. In the rapid mixing step the speed was kept at $120 \mathrm{rpm}$ for $2.5 \mathrm{~min}$, whereas the speed used in the slow mixing step was 20rpm for $20 \mathrm{~min}$ (Konradt et al., 2008). Temperature was maintained at $25.0 \pm 2^{\circ} \mathrm{C}$ during coagulation/flocculation. All experiments were performed at least in triplicate. 


\begin{tabular}{|c|c|c|c|c|c|c|}
\hline \multirow{2}{*}{ Parameter } & \multirow{2}{*}{ CFQ (\%) } & \multicolumn{2}{|c|}{ CFQ - UF (\%) } & \multirow{2}{*}{ CFS (\%) } & \multicolumn{2}{|c|}{ CFS - UF (\%) } \\
\hline & & $\mathrm{P}=1$ bar & $\mathrm{P}=2 \mathrm{bar}$ & & $\mathrm{P}=1 \mathrm{bar}$ & $\mathrm{P}=2 \mathrm{bar}$ \\
\hline Apparent color & 98.1 & 99.4 & 99.1 & 99.8 & 99.2 & 100 \\
\hline True color & 97.1 & 99.2 & 99.1 & 99.3 & 99.1 & 99.8 \\
\hline Turbidity & 99.3 & 99.9 & 99.9 & 99.2 & 99.8 & 99.8 \\
\hline UV-254nm & 85.8 & 91.8 & 99.4 & 83.4 & 96.3 & 88.5 \\
\hline COD & 59.9 & 90.9 & 97.4 & 38.1 & 89.3 & 85.1 \\
\hline Total coliforms & $62.5^{*}$ & 99.0 & 99.0 & 99.0 & 99.0 & 99.0 \\
\hline Escherichia coli & 99.0 & 99.0 & 99.0 & 99.0 & 99.0 & 99.0 \\
\hline TSS & 60.3 & 97.8 & 88.8 & 94.8 & 93.5 & 97.9 \\
\hline TDS & 41.9 & 40.2 & 86.1 & 7.52 & 49.3 & 42.9 \\
\hline
\end{tabular}

*reduction of $62.5 \%$ in the number of CFU/100mL initially present in the surface water. Source: Bergamasco et al., 2011.

Table 2. Removal efficiency (\%) of coagulation/flocculation and coagulation/flocculationultrafiltration processes at 1 bar and 2 bar, using chitosan (CFQ) or aluminum sulfate (CFS) for the coagulation of surface water

Coagulation pretreatment allows a higher rejection of organics by microfiltration (MF) and UF and the cut-off criterion due to initial membrane pore size is no longer valid (Schafer et al., 2001). The most consistent system was CFQ-UF at the pressure of 1 bar, achieving removal efficiencies above $90 \%$ for all parameters assessed, except for TDS, which had $40.2 \%$ removal. But if the use of CFS-UF is considered, TDS removal reached a maximum of $49.3 \%$. Another relevant parameter to be analyzed is COD, whose removal was higher when using CFQ-UF at 2 bar $(97.4 \%)$ than when using CFS-UF at the same pressure (85.1\%). An important point to be evaluated is the type of membrane used for filtration, because depending on the material the membrane is made of, fouling effects may be more or less pronounced, which will result in differences in permeate flux and percent removal of the assessed parameters.

The hybrid process of coagulation with chitosan followed by filtration in $0.1 \mu \mathrm{m}$ pore size polysulfone membrane, resulted more effective for UV-254nm, TOC, and iron removal. Adding chitosan as coagulant, $70 \%$ of UV-254nm absorbing compounds and $47 \%$ of TOC (averaged values) were removed (Bergamasco et al., 2009). In this study the authors evaluated water from the Saint-Charles River in Quebec, Canada, with an initial UV-254nm absorbance value of 0.083-0.091.

One can see that the ceramic membranes can be more effective for water treatment than polysulfone membranes. Comparing the results with two membranes of different materials and same porosity, ceramic membranes led to a reduction of $91.8 \%$ in UV-254nm absorbance (Bergamasco et al., 2011), while the reduction obtained with polysulfone membranes was $70 \%$ (Bergamasco et al., 2009). Chitosan improves the sedimentation step, as the flocs are more compact, which is favorable when hybrid coagulation/flocculation/filtration systems are operated. Another fact that should be taken into consideration when applying UF for water treatment is the occurrence of membrane clogging, which causes a drop in permeate flux and is a result of a set of phenomena related to the solution nature and to the characteristics of the membrane (Bergamasco et al., 2011). This fact can be explained by two 
mechanisms, commonly attributed to the removal of organic matter by UF: sieve retention and adsorption sequestration. In sieve retention the UF membrane acts as a barrier for particle penetration. The particles are retained on the membrane surface and form a cake that grows in thickness as the filtration progresses. The second mechanism involves the entry and capture of the particles into the membrane matrix (Guo et al., 2009).

Bergamasco et al. (2011), using ceramic membrane in the combined process of coagulation/flocculation with chitosan and ultrafiltration, obtained higher permeate fluxes than with UF of surface water (SW) and CFS-UF under the same pressures. For the pressure of 2 bar the permeate flux of the CFQ-UF process was approximately twice that of the CFSUF process, thus justifying the use of chitosan as a coagulant prior to the ultrafiltration step for surface water treatment. The authors presented the results obtained by the resistance-inseries model for the different types of resistance observed in the UF step using SW, CFQ, and CFS at pressures of 1 bar and 2 bar, as shown in Table 3. The coagulation/flocculation conditions to obtain water for use in the ultrafiltration experiments were the same as for the experiments presented in Table 2 .

\begin{tabular}{l|lll}
\hline & \multicolumn{3}{|c}{ Resistance $\mathbf{x 1 0 1 1}\left(\mathbf{m}^{-1}\right)^{*}$} \\
\cline { 2 - 4 } & $\mathrm{R}_{\mathrm{f}}$ & $\mathrm{R}_{\mathrm{cp}}$ & $\mathrm{R}_{\mathrm{t}}$ \\
\hline $\mathbf{S W}$ & & & \\
$\Delta \mathbf{P}=\mathbf{1}$ bar & 1.22 & 6.79 & 9.62 \\
$\Delta \mathbf{P}=\mathbf{2}$ bar & 8.11 & 9.58 & 20.76 \\
\hline $\mathbf{C F Q}$ & & & \\
$\Delta \mathbf{P}=\mathbf{1}$ bar & 4.63 & 0.82 & 7,06 \\
$\Delta \mathbf{P}=\mathbf{2}$ bar & 9.92 & 0.12 & 13.11 \\
\hline $\mathbf{C F S}$ & & & \\
$\Delta \mathbf{P}=\mathbf{1}$ bar & 0.42 & 5.78 & 8.11 \\
$\Delta \mathbf{P}=\mathbf{2}$ bar & 5.89 & 12.89 & 21.86 \\
\hline
\end{tabular}

${ }^{*}$ Rf: fouling resistance; Rcp: concentration polarization resistance; Rt: total resistance.

Source: Bergamasco et al. (2011).

Table 3. Resistances on the membrane during the ultrafiltration process with SW, CFQ, and $\mathrm{CFS}$ at 1 bar and 2 bar, using $\mathrm{Al} 2 \mathrm{O} 3 / \mathrm{ZrO} 2(0.1 \mu \mathrm{m})$ ceramic membranes and filtration time of $200 \mathrm{~min}$.

It was observed by means of Table 3, that for the same type of water (without treatment, coagulated with chitosan, or coagulated with aluminum sulfate) the fouling resistance $\left(R_{f}\right)$ due to solute adsorption into membrane pores and walls (Chang et al., 2001) increased with increasing transmembrane pressure, and this can be explained by the higher compression.

This type of resistance can be eliminated only by washing the membrane. It was also observed that $R_{f}$ was greater for CFQ than for SW and CFS, but concentration polarization resistance $\left(R_{\mathrm{cp}}\right)$ and $\mathrm{R}_{\mathrm{t}}$ were lower for CFQ than for SW and CFS at 1 bar and 2 bar. The floc cake resistance is lower than the resistance due to the unsettled floc and the uncoagulated organics, as reported by Guigui et al. (2002). The use of chitosan as a coagulant can lead to the formation of denser flocs. Thus, its negative impact on the filtration can be explained. The cake is formed by large aggregates, decreasing the average flux through and among these aggregates. However, the performance evaluation of the hybrid systems (CFS-UF and CFQ-UF) showed that the permeate quality was increased when compared with 
individually operated systems (CFS and CFQ). This is justified by the excellent ability of the UF process to remove particles and colloids.

\subsection{Process of coagulation/flocculation with moringa followed by microfiltration for surface water treatment}

The other study on water purification processes performed in the Environmental Preservation and Control Laboratory at the State University of Maringá, Brazil, evaluated the coagulation/flocculation process using the natural coagulant Moringa oleifera, followed by microfiltration (Nishi, 2011). As mentioned previously, surface water from the Pirapó River was used for this study. Samples of high and low turbidity were mixed to obtain water with different initial turbidity values. The samples used in this study had initial turbidity of 50, 150, 250, 350, and 450 NTU. The prepared samples were artificially contaminated with $10^{6}$ cysts/L of Giardia spp. and $10^{6}$ oocysts/L of Cryptosporidium spp. obtained from the positive control (suspension of cysts and oocysts) present in the commercial kit Merifluor (Meridian Bioscience, Cincinnati, OH, USA). After being prepared, the samples were subjected to the processes of coagulation/ flocculation with moringa seeds (CFM), microfiltration (MF), and the combined coagulation/flocculation with moringa seeds followed by microfiltration (CFM-MF).

Moringa coagulant solution was prepared and used the same day. Mature moringa seeds from the Federal University of Sergipe (UFS) were used as raw material. The seeds were manually removed from the dry pods and peeled. To prepare the $1 \%$ stock solution of moringa (concentration of 10,000 mg/L), $1 \mathrm{~g}$ of peeled seeds was crushed and added to 100 $\mathrm{mL}$ of distilled water. Subsequently, the solution was stirred for $30 \mathrm{~min}$ and vacuum filtered (Cardoso et al., 2008; Madrona et al., 2010). From the 1\% stock solution, moringa solutions were prepared with different concentrations: 25, 50, 75, 100, 125, 150, 175, 200, 225, 250, 275, and $300 \mathrm{mg} / \mathrm{L}$. CFM tests were performed on a simple jartest, under the following conditions: rapid mixing speed (RMS) of $100 \mathrm{rpm}$, coagulation time (CT) of $3 \mathrm{~min}$, slow mixing speed (SMS) of $15 \mathrm{rpm}$, flocculation time (FT) of $15 \mathrm{~min}$, and settling time (ST) of 60 min (Madrona et al. 2010).

To determine the coagulant concentrations which resulted in the highest removal of the evaluated parameters, $5 \times 12$ factorial experiment was applied. For the factor "A" five different levels of initial water turbidity were tested: 50, 150, 250, 350, and 450 NTU. Factor "B" consisted of twelve levels of concentration of moringa coagulant. The parameters analyzed in the experiments - color, turbidity, $\mathrm{pH}$, and removal of Giardia and Cryptosporidium - were evaluated in triplicate for each combination of the factors "A" and "B". The results were analyzed by ANOVA using the F test and phase contrast (Nkurunziza et al., 2009) to obtain the optimum concentration of each coagulant for each water sample with initial turbidity of 50 to $450 \mathrm{NTU}$, to be later used in the combined process of coagulation/flocculation/membrane filtration. The software Statistica, version 8.0/2010, was used for the statistical analysis, and $p$ values of less than 0.05 were considered significant.

In this study, the same methodologies described in section 2.1 were used to evaluate the removal efficiency of turbidity and color and the $\mathrm{pH}$ of treated water. The concentration of (oo)cysts of Giardia and Cryptosporidium was assessed by the membrane filtration technique with mechanical extraction and elution (Aldom \& Chagla, 1995; Dawson et al., 1993; Franco et al., 2001). 
The initial characteristics of water samples used in the study are presented in Table 4.

\begin{tabular}{ccc}
\hline Turbidity $(\mathrm{NTU})$ & Color $(\mathrm{uH})$ & $\mathrm{pH}$ \\
\hline 50 & 350 & 7.80 \\
150 & 902 & 7.81 \\
250 & 1000 & 7.50 \\
350 & 1849 & 7.64 \\
450 & 1885 & 7.70 \\
\hline
\end{tabular}

Source: Nishi, 2011

Table 4. Water sample parameters before treatment processes.

The results for the removal efficiency of turbidity, color, Giardia and Cryptosporidium, and $\mathrm{pH}$ values for water after treatment with moringa, under the aforementioned conditions, are presented in Table 5. Using moringa as coagulant agent, turbidity removal ranged from 3 to $97.4 \%$. The lowest removal efficiencies, between 3 and $45.6 \%$, were observed for water with low initial turbidity (50 NTU). Removals above $70 \%$ were observed for the samples with

\begin{tabular}{|c|c|c|c|c|c|c|c|c|c|c|c|c|c|}
\hline \multirow[b]{2}{*}{$\begin{array}{l}\text { Initial turbidity } \\
\text { (NTU) }\end{array}$} & \multirow[b]{2}{*}{$\begin{array}{l}\text { Removal efficiency } \\
(\%)\end{array}$} & \multicolumn{12}{|c|}{ Moringa concentration in the water samples (mg/L) } \\
\hline & & 25 & 50 & 75 & 100 & 125 & 150 & 175 & 200 & 225 & 250 & 275 & 300 \\
\hline \multirow[t]{5}{*}{50} & Turbidity & 27.7 & 23.0 & 20.7 & 33.4 & 33.2 & 35.6 & 44.4 & 45.6 & 41.6 & 27.6 & 10.0 & 3.0 \\
\hline & Color & 0.35 & 0.11 & 1.65 & 3.07 & 4.00 & 6.60 & 22.8 & 27.6 & 30.0 & 26.0 & 15.4 & 16.7 \\
\hline & Giardia & 6.00 & 42.3 & 38.4 & 69.2 & 84.6 & 76.9 & 82.0 & 80.0 & 80.0 & 76.9 & 85.0 & 69.0 \\
\hline & Cryptosporidium & 76.0 & 91.0 & 90.0 & 98.0 & 93.0 & 91.0 & 98.0 & 86.0 & 91.0 & 88.0 & 89.0 & 83.0 \\
\hline & $\mathrm{pH}$ & 7.90 & 8.20 & 8.10 & 8.20 & 8.20 & 8.10 & 8.20 & 7.90 & 8.00 & 8.10 & 8.00 & 7.90 \\
\hline \multirow[t]{5}{*}{150} & Turbidity & 42.0 & 52.4 & 69.8 & 71.0 & 74.0 & 75.8 & 67.7 & 65.3 & 69.0 & 73.6 & 76.0 & 72.0 \\
\hline & Color & 10.0 & 47.5 & 67.0 & 68.8 & 70.8 & 73.5 & 73.5 & 71.4 & 65.0 & 63.4 & 66.4 & 61.6 \\
\hline & Giardia & 74.0 & 97.0 & 85.0 & 98.0 & 94.0 & 98.0 & 98.0 & 98.0 & 97.0 & 97.0 & 91.0 & 82.0 \\
\hline & Cryptosporidium & 42.0 & 50.0 & 77.0 & 81.0 & 81.0 & 92.0 & 92.0 & 92.0 & 85.0 & 92.0 & 81.0 & 58.0 \\
\hline & $\mathrm{pH}$ & 7.93 & 7.96 & 7.85 & 7.74 & 7.8 & 7.76 & 7.70 & 7.74 & 7.81 & 7.74 & 7.72 & 7.68 \\
\hline \multirow[t]{5}{*}{250} & Turbidity & 68.9 & 74.8 & 80.6 & 93.4 & 90.1 & 94.4 & 93.9 & 94.2 & 90.9 & 94.6 & 91.8 & 92.7 \\
\hline & Color & 21.8 & 46.5 & 46.2 & 68.4 & 64.4 & 80.7 & 79.0 & 81.3 & 78.0 & 77.8 & 88.4 & 81.6 \\
\hline & Giardia & 80.0 & 65.0 & 65.0 & 80.0 & 80.0 & 95.0 & 95.0 & 95.0 & 95.0 & 90.0 & 92.5 & 90.0 \\
\hline & Cryptosporidium & 67.0 & 61.0 & 75.0 & 74,0 & 86.0 & 96.0 & 95.0 & 92.0 & 94.0 & 90.0 & 87.0 & 78.0 \\
\hline & $\mathrm{pH}$ & 7.60 & 7.70 & 7.80 & 7.80 & 7.60 & 7.60 & 7.70 & 7.80 & 7.80 & 7.80 & 7.70 & 7.80 \\
\hline \multirow[t]{5}{*}{350} & Turbidity & 49.4 & 62.8 & 70.8 & 75.0 & 82.0 & 90.0 & 93.7 & 95.0 & 96.0 & 95.8 & 96.4 & 92.5 \\
\hline & Color & 47.0 & 82.3 & 76.4 & 94.0 & 94.0 & 88.2 & 97.0 & 97.0 & 94.0 & 88.2 & 94.0 & 94.0 \\
\hline & Giardia & 47.0 & 82.3 & 76.4 & 94.0 & 94.0 & 88.2 & 97.0 & 97.0 & 94.0 & 88.2 & 94.0 & 94.0 \\
\hline & Cryptosporidium & 22.0 & 81.0 & 68.0 & 95.0 & 86.0 & 81.0 & 97.0 & 96.0 & 92.0 & 86.0 & 96.0 & 92.0 \\
\hline & $\mathrm{pH}$ & 7.78 & 7.87 & 7.75 & 7.77 & 7.81 & 7.74 & 7.82 & 7.75 & 7.73 & 7.76 & 7.73 & 7.78 \\
\hline \multirow[t]{5}{*}{450} & Turbidity & 63.0 & 61.0 & 75.0 & 79.9 & 92.0 & 94.0 & 97.2 & 97.4 & 97.2 & 97.0 & 96.7 & 94.7 \\
\hline & Color & 39.0 & 47.8 & 61.6 & 68.5 & 88.3 & 91.5 & 96.1 & 96.1 & 96.4 & 96.0 & 95.6 & 92.8 \\
\hline & Giardia & 63.0 & 92.0 & 96.0 & 96.0 & 92.0 & 96.0 & 90.0 & 97.0 & 94.0 & 97.0 & 93.0 & 89.2 \\
\hline & Cryptosporidium & 45.0 & 51.0 & 94.0 & 85.0 & 80.0 & 94.0 & 86.0 & 93.0 & 95.0 & 98.0 & 90.0 & 76.0 \\
\hline & $\mathrm{pH}$ & 7.80 & 7.70 & 7.60 & 7.60 & 7.60 & 7.60 & 7.00 & 7.60 & 7.60 & 7.60 & 7.50 & 7.60 \\
\hline
\end{tabular}

Source: Nishi, 2011.

Table 5. Percentage of removal efficiency of turbidity, color, Giardia, and Cryptosporidium, and $\mathrm{pH}$ values after the process of coagulation/flocculation with moringa. 
turbidity of 250, 350, and 450 NTU (Nishi, 2011). The decrease in efficiency of turbidity removal from water with 50 NTU of initial turbidity, after the addition of moringa, can be explained by the increased organic load. This is justifiable as long as moringa is an oilseed which is rich in organic substances such as oil, protein, fat, and vitamins. This increase in turbidity and color in water treated with moringa was also observed in other studies, especially when the water had relatively low initial turbidity and color (Ramos, 2005).

Nkurunziza et al. (2009), using a 3\% solution of moringa seeds, prepared with saline water, to treat water from the rivers in the province of Rwanda, obtained removal efficiency of $83.2 \%$ in samples with turbidity of 50 NTU and higher values $(99.8 \%)$ in water with turbidity of 450 NTU. The optimum concentrations found in this study were $150 \mathrm{mg} / \mathrm{L}$ for $50 \mathrm{NTU}$ and $125 \mathrm{mg} / \mathrm{L}$ for other turbidity levels tested by the researchers. The results of turbidity removal from water with low initial turbidity (50 NTU) were higher than those obtained in the present case study $(45.6 \%)$ and for water with high initial turbidity (450 NTU) the results were similar (97.4\%). The differences may be due to the different preparation procedures of the moringa solution, by aqueous or saline extraction, as well as the different concentrations of the stock solution of moringa. In both studies, the coagulant properties of the moringa appear to be more efficient in water of high initial turbidity, in agreement with other literature reports (Ndabigengesere et al., 1995; Madrona et al., 2010).

Ndabigengesere et al. (1995), applying an aqueous solution of $5 \%$ moringa seeds to synthetic turbid water (kaolin added to tap water) with initial turbidity of $426 \mathrm{NTU}$, obtained removals from 80 to $90 \%$ and reached the optimum concentration of $500 \mathrm{mg} / \mathrm{L}$ of coagulant solution. This concentration is higher than the optimum concentration for water of 450 NTU obtained in this case study, which was $275 \mathrm{mg} / \mathrm{L}$. This difference between the optimum concentrations of the moringa solution may be due to the different water source: Ndabigengesere et al. (1995) used synthetic turbid water prepared with kaolin, and the present study used surface water. The different efficiencies of turbidity removal and optimum concentrations can be explained by the different compositions of water samples used in the studies (raw water, synthetic turbid water), that is, the substances present in water can influence the action of the coagulant agent and the formation of flocs, as well as by the preparation procedure of the moringa solution (aqueous or saline extraction), evaluated concentrations, and seed quality, among other factors.

Regarding color, the removal ranged from 0.11 to $30 \%$ for water with initial turbidity of 50 NTU. The highest removals for this sample were obtained with moringa concentration ranging from 175 to $250 \mathrm{mg} / \mathrm{L}$. For water with higher initial turbidity (150 to $450 \mathrm{NTU}$ ), the removal efficiency ranged from 10 to $97 \%$, the highest values being obtained for concentrations of $150 \mathrm{mg} / \mathrm{L}$ or higher (Nishi, 2011). It is observed that color removal by moringa is similar to its behavior with respect to turbidity: the lowest values of this parameter are obtained for water with high initial turbidity, which agrees with literature data (Cardoso et al., 2008; Nkurunziza et al., 2009; Madrona et al., 2010).

Concerning the $\mathrm{pH}$ of water samples after the coagulation process with different concentrations of moringa, it was observed that the average $\mathrm{pH}$ was 7.6, with variation of approximately $10 \%$ (Nishi, 2011). There was little variation among the samples regardless of the amount of moringa solution added, which consists of one of the benefits of moringa as a coagulant agent, that is, its addition does not significantly alter the $\mathrm{pH}$ of the water (Ndabigengesere et al., 1995; Nkurunziza et al., 2009), unlike the treatment with aluminum 
sulfate, in which it is necessary to adjust the $\mathrm{pH}$ of the water to improve its coagulant action, increasing the amount and cost of chemicals for water treatment.

Considering the removal of Giardia cysts and Cryptosporidium oocysts, similar behaviors were observed among samples. The best removal of both Giardia and Cryptosporidium occurred at moringa solution concentrations of $150 \mathrm{mg} / \mathrm{L}$ or higher, for all treated water samples (50 to $450 \mathrm{NTU}$ ), with average removal efficiency of $93 \%$ (1.2 log removal) and 90\% (1 log removal), respectively (Nishi, 2011). No studies were found in the literature regarding the removal of these protozoan parasites using moringa as coagulant agent. The high removal obtained can be explained by the coagulant action of moringa, which is based on the presence of cationic proteins in the seeds. These proteins are densely charged cationic dimers with a molecular weight of about $13 \mathrm{kDa}$, and adsorption and charge neutralization are the main mechanisms of coagulation (Ndabigengesere et al., 1995). Since the zeta potential calculated for (oo)cysts of Giardia and Cryptosporidium in water at neutral $\mathrm{pH}$ are, on average, -17 and $-38 \mathrm{mV}$, respectively (Hsu \& Huang, 2002), the mechanism of charge neutralization of the proteins of the natural coagulant could act in the removal of these protozoan parasites.

The removal of protozoan parasites obtained in this study is close to the results of other reports in the literature, using chemical coagulants such as aluminum sulfate and ferric chloride for the removal of these microorganisms (Bustamante et al., 2001; Xagoraraki \& Harrington, 2004), and neutralization of charges is also the primary mechanism of coagulation with aluminum sulfate. Brown \& Emelko (2009) applied another natural coagulant, chitosan, for the removal of Cryptosporidium parvum in pilot-scale treatment of synthetic raw water (dechlorinated tap water with kaolinite-induced turbidity), using concentrations of $0.1,0.5$, and $1.0 \mathrm{mg} / \mathrm{L}$ chitosan solution. The authors achieved great reductions in turbidity, but did not obtain good results in C. paroum removal, with average values below $10 \%$. A possible explanation for this difference, since chitosan is also a cationic polymer, is the possibility that during the coagulation/flocculation process, the oocysts are also removed by physical entrapment in the flocs, which is another mechanism participating in protozoan removal (Bustamante et al., 2001). Considering that the flocs formed depend on the characteristics of the particles in the water, it can be said that the removal of microorganisms will also depend on these characteristics, as Brown and Emelko (2009) used artificial raw water and in this study natural surface water was used.

Moringa presented good results of color, turbidity, Giardia and Cryptosporidium removal from all water samples for the coagulation/flocculation process, most notably in samples of high initial turbidity $(150,250,350$, and $450 \mathrm{NTU})$ and with coagulant concentration of 100 $\mathrm{mg} / \mathrm{L}$ or higher. The process of coagulation/flocculation with moringa yielded $1.2 \mathrm{log}$ removal for Giardia and 1 log removal for Cryptosporidium. These removals are in line with the recommendations of the World Health Organization (Lechevallier \& $\mathrm{Au}, 2004$ ). According to Lechevallier \& $\mathrm{Au}$ (2004), in the conventional water treatment processes, coagulation is a critical step for the removal of pathogenic microorganisms. Coagulation, flocculation, and sedimentation can result in 1-2 log removal of bacteria, viruses and protozoa when properly handled. Also according to the authors, in the case of Giardia and Cryptosporidium, there is great difficulty in interpreting results in relation to studies on bench scale, as well as on pilot scale, due to the low concentrations at which these protozoa are found and the detection methods, which are still limited. 
Statistical analysis showed that there is a relationship of the turbidity, Giardia and Cryptosporidium removal with the moringa solution concentration and the initial water turbidity. Statistical analysis was applied to obtain the concentration of moringa which showed the best removals of turbidity, Giardia and Cryptosporidium for each initial turbidity of water samples. It was observed that for the sample with turbidity of $50 \mathrm{NTU}$, the concentration of the moringa solution showed no statistically significant interaction with the values of turbidity, Giardia and Cryptosporidium removal. Therefore, it was not possible to obtain the optimum concentration for the water sample with initial turbidity of 50 NTU. For the remaining samples, the moringa solution concentrations which showed the best removal of the evaluated parameters were obtained and are presented in Table 6. It is observed that coagulation/flocculation provided good removal efficiencies of turbidity and color, depending on water characteristics, initial turbidity, and coagulant concentration.

\begin{tabular}{cc}
\hline $\begin{array}{c}\text { Initial turbidity } \\
\text { (NTU) }\end{array}$ & $\begin{array}{c}\text { Optimum concentration } \\
(\mathrm{mg} / \mathrm{L})\end{array}$ \\
\hline 150 & 250 \\
250 & 150 \\
350 & 275 \\
450 & 275 \\
\hline
\end{tabular}

Source: Nishi, 2011.

Table 6. Moringa concentration which resulted in the best removal of turbidity, color, and (oo)cysts of Giardia and Cryptosporidium, according to the initial turbidity of the water sample.

After obtaining the optimal concentrations of moringa coagulant for each sample of surface water (Table 6), the samples were subjected to the MF process and to the combined process of coagulation/flocculation with moringa followed by MF (CFM-MF).

The membrane filtration tests were carried out in a bench-scale microfiltration membrane module, using the tangential filtration principle. This module is shown in Figure 2.

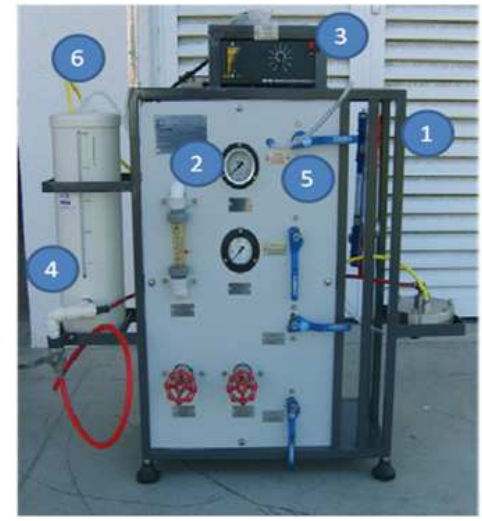

Fig. 2. Frontal view of the MF/UF module (Operation manual - MF/UF module): (1) polymeric membranes; (2) pressure gauges; (3) speed controller; (4) feed tank; (5) valve used to collect the permeate; (6) tubing through which the concentrate returned to the feed tank. 
The MF membrane was composed of hollow fibers made of polyimide, with porosity of 0.40 $\mu \mathrm{m}$. The operating pressure was 1.0 bar. To maintain uniformity in the experiments, the initial volume was fixed in $5 \mathrm{~L}$, and the test time was $60 \mathrm{~min}$.

In this study, the same methodologies described in section 2.1 were used to evaluate membrane flux and fouling, as well as to analyze the removal efficiency of turbidity, color, Giardia and Cryptosporidium, and the $\mathrm{pH}$ of treated water.

The results obtained in the processes of microfiltration (MF) and coagulation/flocculation with moringa followed by microfiltration (CFM-MF) are presented below. These results are presented together to show if the pretreatment (coagulation/flocculation with moringa) had differences in relation to the MF process without pretreatment. The removal efficiencies and the $\mathrm{pH}$ of the water treated by the MF and CFM-MF processes are presented in Table 7.

\begin{tabular}{cccccc}
\hline & & \multicolumn{4}{c}{ Initial turbidity (NTU) } \\
\cline { 3 - 6 } Treatment process & Removal efficiency (\%) & 150 & 250 & 350 & 450 \\
\hline \multirow{3}{*}{ MF } & Turbidity & 81.09 & 84.16 & 76.82 & 76.33 \\
& Color & 78.28 & 83.45 & 74.27 & 72.56 \\
& Giardia & ND & ND & ND & ND \\
& Cryptosporidium & ND & ND & ND & ND \\
& pH & 7.38 & 7.85 & 7.36 & 7.81 \\
\hline \multirow{3}{*}{ CFM-MF } & Turbidity & 93.54 & 92.28 & 84.78 & 99.39 \\
& Color & 96.15 & 92.19 & 88.96 & 100.0 \\
& Giardia & ND & ND & ND & ND \\
& Cryptosporidium & ND & ND & ND & ND \\
& pH & 7.33 & 7.72 & 7.34 & 7.51 \\
\hline
\end{tabular}

ND - not detected. Source: Nishi, 2011

Table 7. Removal efficiencies of turbidity, color, Giardia and Cryptosporidium, and $\mathrm{pH}$ values of the water treated by the MF and CFM-MF processes.

It can be observed that the largest color and turbidity removals occurred with the combined CFM-MF process, compared with the MF process without pretreatment. There were no changes in the $\mathrm{pH}$ of the treated water. It is clear that the use of coagulation/flocculation with moringa prior to microfiltration improves the quality of treated water (Nishi, 2011).

A few studies were found in the literature regarding the $\mathrm{CF} / \mathrm{MF}$ process using moringa as a coagulant for surface water treatment. Madrona (2010) evaluated the combined process of coagulation/flocculation with moringa and MF with ceramic membranes, and obtained 97 to $100 \%$ removal of turbidity and color in the treatment of surface water from the Pirapó River, in Maringá, Paraná. These results were similar to those obtained in the present study, which used a polymer membrane for the MF process. Parker et al. (1999), using hollow fiber MF membranes with $0.2 \mu \mathrm{m}$ pores for the treatment of water that had been previously treated in settling tanks, obtained water with turbidity below $0.1 \mathrm{NTU}$, with average removal of $99.46 \%$, similar to those obtained in this study.

Neither in the microfiltration (MF) process alone, nor in the combined (CFM-MF) processes, (oo)cysts of Giardia and Cryptosporidium were detected in the filtered water, being below the 
detection limit (<1 cyst or oocyst/L) (approximately 6 log removal), in agreement with literature data. Jacangelo et al. (1995), studying the application of three MF membranes with pore sizes between 0.08 and $0.22 \mu \mathrm{m}$ for the treatment of water contaminated with Giardia and Cryptosporidium, found that the protozoa concentration was below detectable levels in the filtered water ( $<1$ cyst or oocyst/L) from two of the membranes (corresponding to log removal $>4.7$ to $>7.0$ for Giardia and $>4.4$ to $>6.9$ for Cryptosporidium). They also concluded that the level of removal depends on the concentration of protozoa in the water to be treated and on membrane integrity. In another study, MF membranes with average pore size of $0.2 \mu \mathrm{m}$ resulted in significant removal of particles that were the same size as Giardia cysts $(5-15 \mu \mathrm{m})$. Log removal was, on average, 3.3 to 4.4 . The removal of particles that were the same size as Cryptosporidium oocysts $(2-5 \mu \mathrm{m})$ was lower, 2.3 to 3.5 log removal. These removals were obtained according to the concentration of (oo)cysts used for artificial contamination of water and proved to be independent of the membrane flux $\left(114-170 \mathrm{~L} / \mathrm{hm}^{2}\right)($ Karimi et al., 1999).

Thus, one can say that MF may act as a barrier against protozoan (oo)cysts. The coagulation/flocculation with moringa associated with microfiltration resulted in high levels of removal of the evaluated parameters.

Figure 3 shows the permeate flux versus time for the microfiltration of deionized water (DW), raw water without coagulant (SW), and pretreated water (CFM).

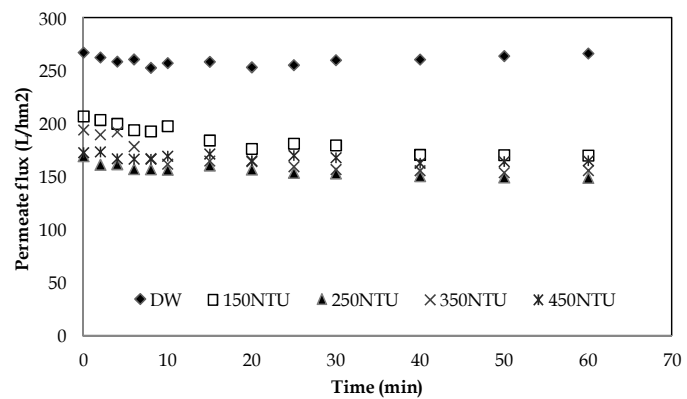

(a)

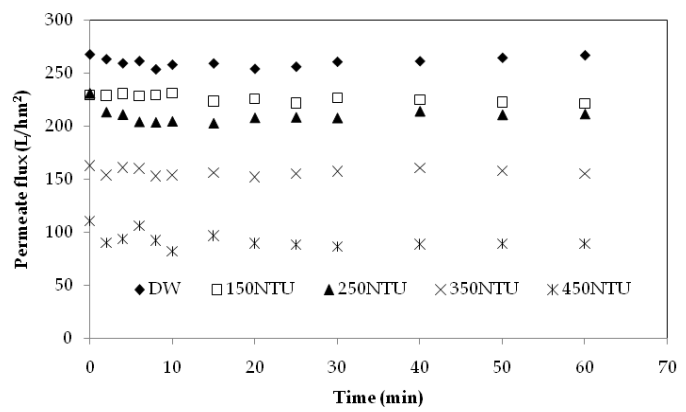

(b)

Source: Nishi, 2011.

Fig. 3. Permeate flux with deionized water (DW) and raw water with initial turbidity from 150 to 450 NTU in the MF (a) and CFM-MF (b) processes. 
For the MF process with raw water, that is, without previous treatment (coagulation/ flocculation), permeate flux ranged from 157 to $187 \mathrm{~L} / \mathrm{hm}^{2}$ for water samples of turbidity from 150 to 450 NTU. In the combined process (CFM-MF), permeate flux ranged from 157 to $226 \mathrm{~L} / \mathrm{hm}^{2}$ for water samples with initial turbidity of 150 to 350 NTU. Samples of 450 NTU presented the lowest permeate flux, $91 \mathrm{~L} / \mathrm{hm}^{2}$, on average (Nishi, 2011). This may be due to the presence of a greater number of particles that can cause the process of concentration polarization and due to superposition of various fouling mechanisms in the membrane, which may cause the decrease of the permeate flux (Stopka et al., 2001).

The combined processes of coagulation/flocculation/microfiltration showed slightly higher fluxes when compared with the microfiltration process alone. The improvement in permeate flux using coagulation/flocculation prior to microfiltration was also observed in other studies (Katayon et al., 2007; Horčičková et al., 2009).

The percentage of fouling $(\% \mathrm{~F})$ for the MF process with raw water $(\mathrm{SW})$ and water coagulated/flocculated with moringa (CFM) with initial turbidity from 150 to $450 \mathrm{NTU}$ is shown in Figure 4.

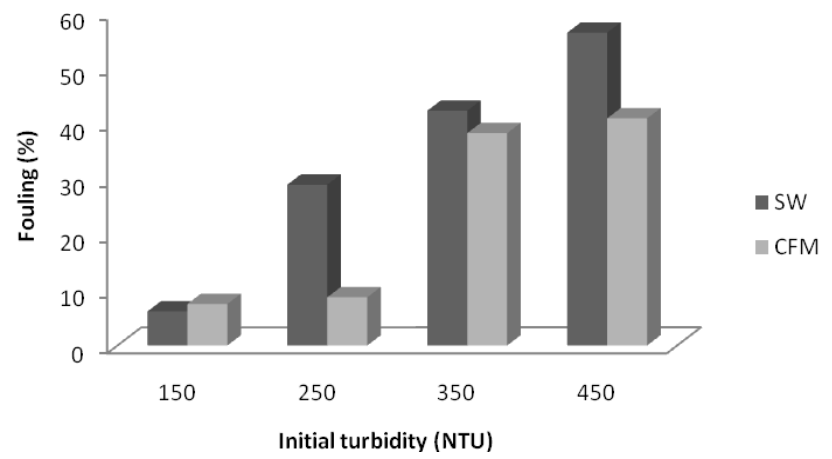

Fig. 4. Percentage of fouling for the MF process with raw water (SW) and water coagulated/flocculated with moringa (CFM) with initial turbidity from 150 to 450 NTU.

It is observed that the MF process with raw water showed higher percentages of fouling, ranging from 6.13 to $56.32 \%$ when compared with the combined process of coagulation/ flocculation with moringa followed by MF, which presented percentages of fouling from 7.48 to $40.9 \%$ (Nishi , 2011). This reduction in membrane fouling when using the process of coagulation/flocculation as pretreatment was also observed in other studies. Madrona (2010) used coagulation/ flocculation with moringa, followed by MF with ceramic membranes with porosity of 0.1 and $0.2 \mu \mathrm{m}$, for the treatment of surface water and observed fouling percentages of around $94 \%$ during the filtration of raw water and slightly lower values, around $88 \%$, when water previously coagulated/flocculated with moringa was filtered. Carroll et al. (2000) used polypropylene hollow fiber MF membrane to filter surface water from the Moorabool River, Australia, and observed fouling percentages of $80 \%$ for water without pretreatment and $50 \%$ for water pretreated by coagulation with alum.

According to Cheryan (1998), the type and extent of fouling depend on the chemical nature of the membrane, the solute, and the solute-membrane interactions, as well as on the porosity of the membrane and the working pressure used in the process. 


\section{Conclusions}

Performance evaluation of the hybrid systems (CFS-UF, CFQ-UF, and CFM-MF) showed that the permeate quality was increased when compared with individually operated systems. This is justified by the excellent ability of the MF/UF process to remove particles and colloids. The results also indicate that when applying CF-MF/UF at optimum conditions, a hygienic barrier effect was achieved for the treatment scheme, in which nearly $100 \%$ removal of total coliforms, E. coli, Giardia and Cryptosporidium was obtained at the end of the process. In addition, the combined processes CFQ-UF, CFM-MF, and CFS-UF produced drinking water in accordance with the legislation.

Given the above considerations, one can say that chitosan and Moringa oleifera have a potential application as natural coagulants in CF-MF/UF hybrid processes for treating drinking water with relatively high turbidity. This process can be used reliably to produce drinking water of excellent quality.

\section{List of abbreviations}

Coagulation $/$ flocculation $=\mathrm{CF}$

Coagulation/flocculation using chitosan as coagulant $=\mathrm{CFQ}$

Coagulation/flocculation using aluminum sulfate as coagulant $=$ CFS

Coagulation/flocculation using chitosan as coagulant followed by ultrafiltration $=$ CFQ-UF

Coagulation/flocculation using aluminum sulfate as coagulant followed by ultrafiltration = CFS-UF

Coagulation/flocculation using moringa as coagulant $=\mathrm{CFM}$

Coagulation/flocculation using moringa as coagulant followed by microfiltration $=\mathrm{CFM}-\mathrm{MF}$

Microfiltration $=\mathrm{MF}$

Ultrafiltration $=$ UF

Moringa oleifera $=$ moringa

Natural organic matter $=\mathrm{NOM}$

\section{References}

Akhtar, M., Moosa Hasany, S., Bhanger, M. I. \& Iqbal, S. (2007). Sorption potential of Moringa oleifera pods for the removal of organic pollutants from aqueous solutions. Journal of Hazardous Materials, Vol. 141, No. 3, pp. 546-556.

Aldom, J.E. \& Chagla, A.H. (1995). Recovery of Cryptosporidium oocysts from water by a membrane filter dissolution method. Letters in Applied Microbiology, Vol. 20, pp. 186187.

American Public Health Association [APHA]. [1995]. Standard Methods for the Examination for Water and Wastewater (19th edition). Byrd Prepess Springfield, ISBN 0875532233, Washington.

Balakrishnan, M., Dua, M. \& Khairnar, P.N. (2001). Significance of membrane type and feed stream in the ultrafiltration of sugarcane juice. Journal of Separation Science and Technology, Vol. 36, No. 4, pp. 619-637.

Bergamasco, R., Bouchard, C., da Silva, F.V., Reis, M.H.M., Fagundes-Klen, M.R. (2009). An application of chitosan as a coagulant/flocculant in a microfiltration process of natural water. Desalination, Vol. 245, pp. 205-213. 
Bergamasco, R., Konradt-Moraes, L.C., Vieira, M.F., Fagundes-Klen, M.R. \& Vieira, A.M.S. (2011). Performance of a coagulation-ultrafiltration hybrid process for water supply treatment. Chemical Engineering Journal, Vol. 166, pp. 483-489.

Bhatia, S., Othman, Z. \& Ahmad, A.L. (2007). Pretreatment of palm oil mill effluent (POME) using Moringa oleifera seeds as natural coagulant. Journal of Hazardous Materials, Vol. 145, No. 1-2, pp. 120-126.

Bottino, A., Capannelli, C., Del Borghi, A., Colombino, M. \& Conio, O. (2001). Water treatment for drinking purpose: ceramic microfiltration application. Desalination, Vol. 141, pp. 75-79.

Bouchard, C., Laflamme, E., Serodes, J., Ellis, D., Rahni, M. \& Rodrigues, M. (2003). Étude en la laboratorie de I'ultrafiltration et de la coagulation-ultrafiltration d'une eau colorée. Proceedings of 17éme Symposium de I'Est du Canada sur la Recherche Portant sur la Pollution de I'eau.

Brown, T.J. \& Emelko, M.B. (2009). Chitosan and metal salt coagulant impacts on Cryptosporidium and microsphere removal by filtration. Water Research, Vol. 43, No. 331-338.

Bustamante, H.A., Shanker, S.R., Pashley, R.M. \& Karaman, M.E. (2001). Interaction between Cryptosporidium oocysts and water treatment coagulants. Water Research, Vol. 35, pp. 3179-3189.

Cardoso, K.C., Bergamasco, R., Cossich, E.S. \& Konradt-Moraes, L.C. (2008). Otimização dos tempos de mistura e decantação no processo de coagulação/floculação da água bruta por meio da Moringa oleifera Lam. Acta Scientiarum - Technology, Vol. 30, pp. 193-198.

Carroll, T., King, S., Gray, S. R., Bolto, B. A. \& Booker, N. A. (2000). The fouling of microfiltration membranes by nom after coagulation treatment. Water Research, Vol. 34, No. 11, pp. 2861 - 2868.

Centers for Disease Control and Prevention [CDC]. (2006). Surveillance Summaries, December 22. MMWR, 55 (No. SS-12).

Chang, I.S., Bag, S.O. \& Lee, C.H. (2001). Effects of membrane fouling on solute rejection during membrane filtration of activated sludge. Process Biochemistry, Vol. 36, pp. $855-860$.

Cheryan, M. (1998). Ultrafiltration and microfiltration handbook. Technomic Publishing CO, Illinois, Lancaster, USA.

Chuang, P.H., Lee, C.W., Chou, J.Y., Murugan, M., Shieh, B.J. \& Chen, H.M. (2007). Antifungal activity of crude extracts and essential oil of Moringa oleifera Lam. Bioresource Technology, Vol. 98, pp. 232-236.

Chung, Y.C., Wang, H.L., Chen, Y.M. \& Li, S.L. (2003). Effect of abiotic factors on the antibacterial activity of chitosan against waterborne pathogens. Bioresource Tech., Vol. 88, pp. 179-184.

Coelho, J.S., Santos, N.D.L., Napoleão, T.H., Gomes, F.S., Ferreira, R.S., Zingali, R.B., Coelho, L.C.B.B., Leite, S.P., Navarro, D.M.A.F. \& Paiva P.M.G. (2009). Effect of Moringa oleifera lectin on development and mortality of Aedes aegypti larvae. Chemosphere, Vol. 77, No. 7, pp. 934-938.

Davino, F. (1976). Tecnologia de tratamento de água: água na indústria. Almeida Neves, Rio de Janeiro, Brazil. 
Dawson, D.J., Maddocks, M., Roberts, J. \& Vidler, J.S. (1993). Evaluation of recovery of Cryptosporidium paroum oocysts using membrane filtration. Letters in Applied Microbiology, Vol. 17, pp. 276-279.

Divakaran, R. \& Pillai, V.N.S. (2002). Flocculation of river silt using chitosan. Water Research, Vol. 36, No. 9, pp. 2414-2418.

Driscoll, C.T. \& Letterman, R.D. (1995). Factors regulating residual aluminium concentrations in treated waters. Environmetrics, Vol. 6, pp. 287-309.

Eikebrokk, B. (1999). Coagulation-direct filtration of soft, low alkalinity humic waters. Water Science and Technology, Vol. 40, No. 9, pp. 55-62.

Eikebrokk, B. \& Saltnes, T. (2001). Removal of natural organic matter (NOM) using different coagulants and lightweight expanded clay aggregate filters. Water Science $\mathcal{E}$ Technology: Water Supply, Vol. 1, No. 2, pp. 131-140.

Fayer, R. (2004). Cryptosporidium: a water-borne zoonotic parasite. Veterinary Parasitology, Vol. 126, pp. 37-56.

Franco, R.M.B., Rocha-Eberhardt, R. \& Cantusio Neto, R. (2001). Occurrence of Cryptosporidium oocysts and Giardia cysts in raw water from the Atibaia river, Campinas, Brazil. Rev. Inst. Med. Trop. S. Paulo, Vol. 43, No. 2, pp. 109-111.

Ghebremichael, K.A., Gunaratna, K.R., Henriksson, H., Brumer, H. \& Dalhammar, G. (2005). A simple purification and activity assay of the coagulant protein from Moringa oleifera seed. Water Research, Vol. 39, No. 11, pp. 2338-2344.

Guigui, C., Rouch, J.C., Durand-Bourlier, L., Bonnelye, V. \& Aptel, P. (2002). Impact of coagulation conditions on the in-line coagulation/uf process for drinking water production. Desalination, Vol. 147, pp. 95-100.

Guo, X., Zhang, Z., Fang, L. \& Su, L. (2009). Study on ultrafiltration for surface water by a polyvinylchloride hollow fiber membrane. Desalination, Vol. 238, pp. 183-191.

Horčičková, J., Mikulášek, P. \& Dvořáková, J. (2009). The effect of pre-treatment on crossflow microfiltration of titanium dioxide dispersions. Desalination, Vol. 240, pp. 257-261.

Hsu, B.M. \& Huang, C. (2002). Influence of ionic strength and $\mathrm{pH}$ on hydrophobicity and zeta potential of Giardia and Cryptosporidium. Colloids and Surfaces A: Physicochemical and Engineering Aspects, Vol. 201, pp. 201-206.

Iacovski, R.B., Barardi, C.R.M. \& Simões, C.M.O. (2004). Detection and enumeration of Cryptosporidium sp. oocysts in sewage sludge samples from the city of Florianópolis (Brazil) by using immunomagnetic separation combined with indirect immunofluorescence assay. Waste Manage Res., Vol. 22, pp. 171-176.

International Water Association [IWA]. (2010). Coagulation and Flocculation in Water and Wastewater Treatment. In: Water Wiki, april 28 ${ }^{\text {Th }}$ 2011, Available from: http://iwawaterwiki.org/xwiki/bin/view/Articles/CoagulationandFlocculationi nWaterandWastewaterTreatment.

Jacangelo, J. G., Adham, S. S. \& Laîné, J-M. (1995). Mechanism of Cryptosporidium, Giardia and MS2 virus removal by MF and UF. Journal of the American Water Works Association, Vol. 87, No. 9, pp. 107-121.

Karimi, A.A., Vickers, J.C. \& Harasick, R.F. (1999). Microfiltration goes Hollywood: the Los Angeles experience. Journal of the American Water Works Association, Vol. 91, No. 6, pp. 90-103. 
Katayon, S., Noor, M.J.M.M., Asma, M., Ghani, L.A.A., Thamer, A.M., Azni, I., Ahmad, J., Khor, B.C. \& Suleyman, A.M. (2006). Effects of storage conditions of Moringa oleifera seeds on its performance in coagulation. Bioresource Technology, Vol. 97, No. 13, pp. 1455-1460.

Katayon, S., Noor, M.J.M.M., Tat, W.K, Halim, G.A., Thamer, A.M. \& Badronisa, Y. (2007). Effect of natural coagulant application on microfiltration performance in treatment of secondary oxidation pond effluent. Desalination, Vol. 204, pp. 204-212.

Kawamura, S. (1991). Effectiveness of natural polyelectrolytes in water treatment. Journal Awa, Japan, Vol. 79, No. 6, pp. 88-91.

Kim, M.H. \& Yu, M.J. (2005). Characterization of NOM in the Han River and evaluation of treatability using UF - NF membrane, Environmental Research, No. 97, pp. 116 123.

Klopotek, A.D., Wlaasiuky, D. \& Klopotek, B.B. Compounds based on chitosan as coagulants and flocculants, Proceedings of International Conference on Chitin and Chitosan, Gydnia, Poland, August, 1994.

Konradt-Moraes, L.C. (2004). Estudo da coagulação-ultrafiltração para produção de água potável. Master of Science Thesis, Universidade Estadual de Maringá - Maringá, PR, Brasil, 135 pp. (in Portuguese).

Konradt, L.C.; Bergamasco, R.; Tavares, C.R.G.; Bongiovani, M.C. \& Hennig, D. (2008). Utilization of the coagulation diagram in the evaluated of the natural organic matter (NOM) removal for obtaining potable water, International Journal of Chemical Reactor Engineering, No. 6, pp. 1 - 6.

Lechevallier, M.W. \& Au, K. (2004). Water treatment and pathogen control: process efficiency in achieving safe drinking water. WHO Drinking Water Quality Series, UK, 136pp.

Lindquist, A. (1999). Emerging pathogens of concern in drinking water. United States Environmental Protection Agency, EPA, 600/R-99/070.

McLachlan, D.R.C. (1995). Aluminum and the risk for Alzheimer's Disease. Environmetrics, Vol. 6, pp. 233-275.

Madrona, G.S., Serpelloni, G.B., Vieira, A.M.S., Nishi, L., Cardoso, K.C \& Bergamasco, R. (2010). Study of the effect of saline solution on the extraction of the Moringa oleifera seed's active component for water treatment. Water, Air, \& Soil Pollution, Vol. 211, pp. 409-415.

Madrona, G.S. (2010). Extração/purificação do composto ativo da semente da Moringa oleifera Lam e sua utilização no tratamento de água para consumo humano. Doctoral Thesis, Universidade Estadual de Maringá - Maringá, PR, Brasil, 176 pp. (in Portuguese).

Muyibi, S.A. \& Evison, L.M. (1995). Moringa oleifera seeds for softening hardwater. Water Research, Vol. 29, No. 4, pp. 1099-1105.

Ndabigengesere A., Narasiah, K.S. \& Talbot, B.G. (1995). Active agents and mechanism of coagulation of turbid waters using Moringa oleifera. Water Research, Vol. 29, No. 2, pp. 703-710.

Nishi, L. (2011). Estudo dos processos de coagulação/floculação seguido de filtração com membranas para remoção de protozoários parasitas e células de cianobactérias. Doctoral Thesis, Universidade Estadual de Maringá - Maringá, PR, Brasil, 203 pp. (in Portuguese). 
Nkurunziza, T., Nduwayezu, J.B., Banadda, E.N. \& Nhapi, I. (2009). The effect of turbidity levels and Moringa oleifera concentration on the effectiveness of coagulation in water treatment. Water Science and Technology, Vol. 59, pp. 1551-1558.

Okuda, T., Baes, A.U., Nishijima, W. \& Okada, M. (1999). Improvement of extraction method of coagulation active components from Moringa oleifera seed. Water Research, Vol. 33, No. 15, pp. 3373-3378.

Okuda, T., Baes, A.U., Nishijima, W. \& Okada, M. (2001). Isolation and characterization of coagulant extracted from Moringa oleifera seed by salt solution. Water Research, Vol. 35, No. 2, pp. 405-410.

Parker, D.Y., Leonard, M.J., Barber, P., Bonic, G., Jones W. \& Leavell, K.L. Microfiltration treatment of filter backwash recycle water from a drinking water treatment facility. Proceedings of American Water Works Association Water Quality Technology Conference. Denver, CO, 1999.

Ramos, R.O. (2005). Clarification of water with low turbulence and moderate color using seeds of Moringa oleifera. Doctoral Thesis. State University of Campinas Campinas,SP, Brazil. 276 pages. (in Portuguese).

Reddy, V.; Urooj, A. \& Kumar, A. (2005). Evaluation of antioxidant activity of some plant extracts and their application in biscuits. Food Chemistry, Vol. 90, pp. 317-321.

Renault, F., Sancey, B., Badot, P.M. \& Crini, G. (2009). Chitosan for coagulation/flocculation processes-an eco-friendly approach. European Polymer Journal, Vol. 45, pp. 13371348.

Rey, L. (2001). Parasitologia (3th edition). Guanabara Koogan, ISBN 8527706776, Rio de Janeiro, Brazil.

Rinaudo, M. (2006). Chitin and chitosan: properties and applications. Progress in Polymer Science, Vol. 31, pp. 603-632.

Rizzo, L., Di Gennaro, A., Gallo, M. \& Belgiorno, V. (2008). Coagulation/chlorination of surface water: a comparison between chitosan and metal salts. Separation and Purification Technology, Vol. 62, pp. 79-85.

Roussy, J., Van Vooren, M., Dempsey, B.A. \& Guibal, E. (2005). Influence of chitosan characteristics on the coagulation and the flocculation of bentonite suspensions. Water Research, Vol. 39, pp. 3247-3258.

Schafer, A.I., Fane, A.G. \& Waite, T.D. (2001). Cost factors and chemical pretreatment effects in the membrane filtration of waters containing natural organic matter,. Water Research, Vol. 35, pp. 1509-1517.

Stopka, J., Bugan, S.G., Broussous, L., Schlosser, S. \& Larbot, A. (2001). Microfiltration of beer yeast suspensions through stamped ceramic membranes. Separation and Purification Technology, Vol. 25, pp. 535-543.

United States Environmental Protection Agency [USEPA]. (1996). National Primary Drinking Water Regulations: Monitoring Requirements for Public Drinking Water Supplies, Final Rule, 40CFR Part 141.

Verbych, S., Bryk, M., Alpatova, A. \& Chornokur, G. (2005). Ground water treatment by enhanced ultrafiltration. Desalination, Vol. 179, No. 1-3, pp. 237-244.

Vieira, A.M.S., Vieira, M.F., Silva, G.F., Araújo, A.A., Fagundes-Klen, M.R., Veit, M.T. \& Bergamasco, R. (2010). Use of Moringa oleifera Seed as a Natural Adsorbent for Wastewater Treatment. Water, Air, E Soil Pollution, Vol. 206, pp. 273-281. 
Xagoraraki, I. \& Harrington, G.W. (2004). Zeta potential, dissolved organic carbon, and removal of Cryptosporidium oocysts by coagulation and sedimentation. Journal of Environmental Engineering, Vol. 130, pp. 1424-1432.

Xia, S., Li, X., Zhang, Q., Xu, B. \& Li, G. (2007). Ultrafiltration of surface water with coagulation pretreatment by streaming current control. Desalination, Vol. 204, pp. 351-358. 


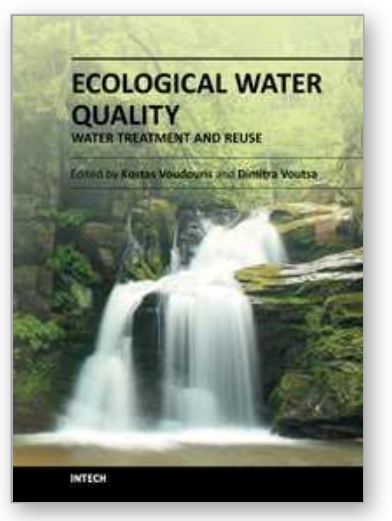

\author{
Ecological Water Quality - Water Treatment and Reuse \\ Edited by Dr. Voudouris
}

ISBN 978-953-51-0508-4

Hard cover, 496 pages

Publisher InTech

Published online 16, May, 2012

Published in print edition May, 2012

This book attempts to cover various issues of water quality in the fields of Hydroecology and Hydrobiology and present various Water Treatment Technologies. Sustainable choices of water use that prevent water quality problems aiming at the protection of available water resources and the enhancement of the aquatic ecosystems should be our main target.

\title{
How to reference
}

In order to correctly reference this scholarly work, feel free to copy and paste the following:

Rosangela Bergamasco, Angelica Marquetotti Salcedo Vieira, Leticia Nishi, Álvaro Alberto de Araujo and Gabriel Francisco da Silva (2012). Application of Hybrid Process of Coagulation/Flocculation and Membrane Filtration to Water Treatment, Ecological Water Quality - Water Treatment and Reuse, Dr. Voudouris (Ed.), ISBN: 978-953-51-0508-4, InTech, Available from: http://www.intechopen.com/books/ecological-water-qualitywater-treatment-and-reuse/application-of-hybrid-process-of-coagulation-flocculation-and-membrane-filtrationto-water-treatment

\section{INTECH}

open science | open minds

\section{InTech Europe}

University Campus STeP Ri

Slavka Krautzeka 83/A

51000 Rijeka, Croatia

Phone: +385 (51) 770447

Fax: +385 (51) 686166

www.intechopen.com

\section{InTech China}

Unit 405, Office Block, Hotel Equatorial Shanghai

No.65, Yan An Road (West), Shanghai, 200040, China

中国上海市延安西路65号上海国际贵都大饭店办公楼 405 单元

Phone: +86-21-62489820

Fax: +86-21-62489821 
(C) 2012 The Author(s). Licensee IntechOpen. This is an open access article distributed under the terms of the Creative Commons Attribution 3.0 License, which permits unrestricted use, distribution, and reproduction in any medium, provided the original work is properly cited. 